\title{
Implementasi Jaringan Internet Guna Meningkatkan Pelayanan Pemerintah Desa di Kecamatan Sembalun
}

\author{
Muhamad Sadali*1, Yupi Kuspandi Putra ${ }^{2}$, Yahya ${ }^{3}$, Intan Komala Dewi ${ }^{4}$ \\ sadali2022@gmail.com ${ }^{* 1}$ \\ ${ }^{1}$ Teknik Informatika, Fakultas Teknik, Universitas Hamzanwadi \\ 2,3, Sistem Informasi, Fakultas Teknik, Universitas Hamzanwadi \\ 4, Teknik Komputer, Fakultas Teknik, Universitas Hamzanwadi
}

Received: 31 October 2021 Accepted: 07 December 2021 Online Published: 30 December 2021

DOI: 10.29408/ab.v2i2.4356

\begin{abstract}
Abstrak: Jaringan Internet saat ini sudah menjadi kebutuhan dasar untuk semua kantor pemerintahan, dari pemerintahan pusat sampai pemerintahan desa. Hal ini karena Pemerintah Indonesia sudah membangun sistem yang terintegrasi secara online. Oleh sebab itu, pengabdian ini bertujuan untuk membantu semua pemerintah desa di Kecamatan Sembalun dalam meningkatkan pelayanan bagi masyarakat dalam bidang teknologi informasi. Sasaran kegiatan adalah Kecamatan Sembalun yang menjadi mitra utama. Target dan luaran pengabdian ini adalah terbangunnya fasilitas jaringan internet pemerintah desa di Kecamatan Sembalun guna meningkatkan pelayanan di bidang teknologi informasi dan komunikasi. Metode yang digunakan adalah dengan melakukan pendekatan partisipasi dalam pengembangan masyarakat atau Participatory Rural Appraisal (PRA). Hasil pengabdian ini adalah 1) pemerintah desa sangat terbantu dengan adanya fasilitas jaringan internet, 2) perangkat desa dapat menyelesaikan pekerjaannya yang berbasis online, 3) pemerintah desa dapat meningkatkan pelayanan di bidang teknologi informasi dan komunikasi. Dengan adanya pengabdian kepada masyarakat yang telah dilakukan, diharapkan dapat membantu semua pemerintah desa yang ada di Kecamatan Sembalun untuk melaksanakan tugas dengan maksimal serta dapat meningkatkan pelayanan bagi masyarakat.
\end{abstract}

Kata kunci: Jaringan Internet; Participatory Rural Appraisal; Pengembangan Infrastruktur Desa

\begin{abstract}
Internet network has become a basic need for all government offices, from central to village governments. This is because the Indonesian government has built an integrated online system. Therefore, this service aims to assist all village governments in Sembalun District in improving services for the community in information technology. The target of the activity is Sembalun District which is the leading partner. The target and outcome of this service are establishing an internet network facility of a village government in Sembalun District to improve services in information and communication technology. The method used is a participatory approach to community development or Participatory Rural Appraisal (PRA). The results of this service are: 1) The internet network facility greatly helps the village government, 2) Village officials can complete their work based online, 3) The village government can improve services in information and communication technology. With the community service that has been carried out, it is hoped that it can help all village governments in Sembalun District carry out their duties to the maximum and improve services for the community.
\end{abstract}

Keywords: Internet Network; Participatory Rural Appraisal; Village Infrastructure Development 
Sadali, M., Putra, Y. K., Yahya, Y., Dewi, I. K. (2021). Implementasi jaringan internet guna meningkatakan pelayanan pemerintah desa di Kecamatan Sembalun. ABSYARA: Jurnal Pengabdian Pada Masyarakat, 2(2), 264-273. doi:10.29408/ab.v2i2.4356

\section{PENDAHULUAN}

Perkembangan teknologi informasi dan komunikasi tidak lepas dari kemajuan teknologi jaringan internet. Pada masa pandemi sekarang ini, penggunaan teknologi informasi dan komunikasi semakin meningkat, ditandai dengan berbagai kegiatan yang dilakukan secara daring dalam bidang ekonomi, budaya, politik, kesehatan, pendidikan, maupun sosial. Salah satunya adalah dalam pembelajaran yaitu pembuatan dan editing video membuka wawasan dan kreativitas guru dalam memanfaatkan teknologi informasi dalam menyampaikan materi pembelajaran (Kholisho, dkk., 2021). Siswa juga dapat memanfaatkan teknologi dalam pembelajaran, seperti pemanfaatan internet sebagai sumber belajar (Rasmila, dkk., 2021). Dalam bidang kewirausahaan yaitu yang memiliki ide-ide kreatif dengan memanfaatkan kemajuan teknologi dapat menjadi pelaku usaha dan melakukan pengembangan usaha secara mandiri (Suhartini, dkk., 2021).

Internet merupakan media penghubung antara satu hal dengan hal yang lainnya, sehingga terbentuk suatu kelompok baru di dunia virtual. Selain itu internet juga merupakan suatu sistem yang digunakan di seluruh dunia sebagai penghubung hardware yang mengirim data digital melalui software. Internet juga bisa dikatakan sebagai alat komunikasi antar ruang (Pibriana \& Ricoida, 2017). Implementasi teknologi internet dimulai dengan pembangunan topologi jaringan dengan menggunakan WIFI sebagai transmitter (Purbo, 2006). Dibutuhkan sebuah Access Point untuk menggunakan jaringan wireless dengan jangkauan yang luas. Pada saat menggunakan Access Point yang banyak, dibutuhkan seorang administrator untuk mengonfigurasi setingannya dan memelihara jaringan tersebut (Towidjojo \& Farhan, 2015). Teknologi Wireless Lan juga digunakan dalam layanan internet berbasis Hotspot sehingga pengguna dapat mengakses internet dengan berbagai media (Purwanto, 2015).

Kegiatan pengabdian Bina Desa merupakan salah satu Program Kompetisi Kampus Merdeka yang diselenggarakan oleh Program Studi Teknik Informatika Fakultas Teknik Universitas Hamzanwadi dan lokasi kegiatan ini berada di kecamatan Sembalun. Sembalun merupakan sebuah kecamatan di kabupaten Lombok Timur, Nusa Tenggara Barat. Kecamatan Sembalun terdiri dari 6 desa, yaitu Sembalun Bumbung, Sembalun Lawang, Sembalun Timba Gading, Sembalun, Sajang, dan Bilok Petung. Kecamatan Sembalun memiliki luas wilayah sekitar $217,08 \mathrm{~km}^{2}$ dan berada pada dataran tinggi berkisar antara 390-1180 meter di atas permukaan laut. Kecamatan Sembalun memiliki keindahan alam yang sangat eksotik, sehingga menjadi daya tarik tersendiri bagi wisatawan lokal maupun mancanegara. Sebagian besar mata pencaharian masyarakatnya adalah dari sektor pertanian dan pariwisata.

Berdasarkan hasil pengamatan dari tim dosen, salah satu permasalahan pemerintah desa di kecamatan Sembalun adalah jaringan internet. Sebelumnya sebagian pemerintah desa yang ada di kecamatan Sembalun sudah memiliki jaringan internet dan itu merupakan bantuan dari pemerintah daerah, akan tetapi sering mengalami gangguan bahkan sampai saat ini jaringan internet tersebut tidak dapat digunakan, sehingga menyebabkan terganggunya aktivitas pemerintah desa dan pelayanan kepada masyarakat yang berbasis online tidak maksimal. Oleh karena itu, solusi untuk mengatasi permasalahan tersebut adalah dengan menerapkan teknologi jaringan internet untuk meningkatkan pelayanan bagi masyarakat di kecamatan Sembalun. 
Sadali, M., Putra, Y. K., Yahya, Y., Dewi, I. K. (2021). Implementasi jaringan internet guna meningkatakan pelayanan pemerintah desa di Kecamatan Sembalun. ABSYARA: Jurnal Pengabdian Pada Masyarakat, 2(2), 264-273. doi:10.29408/ab.v2i2.4356

\section{METODE PELAKSANAAN}

\section{Waktu dan Lokasi}

Kegiatan pengabdian Bina Desa merupakan salah satu Program Kompetisi Kampus Merdeka ini dilaksanakan mulai tanggal 14 Juli sampai dengan 14 November 2021, dan lokasi kegiatan ini di Kecamatan Sembalun. Peserta kegiatan adalah mahasiswa program studi Teknik Informatika dan Tim Dosen.

\section{Prosedur pelaksanaan}

Metode yang digunakan dalam pengabdian ini adalah Participatory Rural Appraisal (PRA). PRA merupakan suatu pendekatan atau metode yang mempelajari kehidupan dan kondisi pedesaan dengan cara berkegiatan dari masyarakat, dengan masyarakat, dan oleh masyarakat pedesaan itu sendiri. Beberapa langkah dalam pendekatan PRA yaitu analisis kebutuhan/identifikasi masalah; pemilihan alternatif pemecahan masalah yang tepat; perencanaan untuk mengimplementasikan ide-ide pemecahan masalah yang dipilih; pelaksanaan rencana; monitoring kegiatan; dan evaluasi kegiatan sebagai refleksi rencana tindak lanjutan ke depan (Narayanasamy, 2009). Adapun tahapan pelaksanaan pengabdian bina desa ini adalah sebagai berikut:

1. Persiapan

Sebelum kegiatan dimulai Tim dosen melakukan persiapan dengan memilih lokasi atau tempat kegiatan pengabdian yang dijadikan sebagai mitra. Setelah menentukan mitra kemudian melakukan koordinasi dengan tim dosen tentang persiapan yang dilakukan sebelumnya. Tim dosen juga harus mempersiapkan alat dan bahan yang dibutuhkan dalam proses kegiatan pengabdian.

2. Pelaksanaan

Pelaksanaan kegiatan pengabdian pada masyarakat ini mulai dilakukan tanggal 14 Juli 2021 dengan acara pembukaan bersama tim dosen dengan pemerintah Kecamatan Sembalun. Selanjutnya pada bulan Agustus tim dosen melakukan identifikasi permasalahan jaringan yang ada pada semua kantor desa di Kecamatan Sembalun. Berdasarkan hasil identifikasi tim dosen mempersiapkan alat dan bahan yang dibutuhkan dalam membangun sebuah jaringan internet. Setelah alat dan bahan tersedia tim dosen melakukan pengecekan dan konfigurasi terhadap modem+router yang akan didistribusikan ke setiap kantor desa di Kecamatan Sembalun. Selanjutnya tim dosen bersama mahasiswa melakukan pemasangan modem +router pada semua kantor desa di Kecamatan Sembalun.

3. Evaluasi

Pada tahap evaluasi tim dosen melakukan koordinasi kembali untuk melihat sejauh mana pemanfaatan perangkat jaringan yang ada di semua kantor desa di Kecamatan Sembalun, serta perangkat jaringan tersebut berfungsi dengan baik atau tidak. Kemudian masuk ke tahap akhir yaitu membuat laporan akhir dari semua kegiatan yang telah dilakukan selama pengabdian bina desa.

4. Rencana Tindak Lanjut

Tahapan tindak lanjut atau pengembangan selanjutnya pada infrastruktur jaringan yang ada di semua kantor desa adalah membutuhkan perangkat tambahan jaringan yaitu mikrotik. Hal ini sejalan dengan penelitian Purwanto (2015), menjelaskan bahwa 
pengembangan dan implementasi jaringan hotspot menggunakan router mikrotik memerlukan hardware tambahan berupa lancard, routerboard mikrotik atau PC router mikrotik, kabel UTP dan access point. MikroTik Router adalah salah satu sistem operasi yang dapat digunakan sebagai router jaringan yang handal, mencakup berbagai fitur lengkap untuk jaringan dan wireless (Riadi, 2011).

\section{HASIL DAN PEMBAHASAN}

\section{HASIL}

Kegiatan ini diawali dengan acara pembukaan dan sekaligus penyerahan peserta program kompetisi kampus merdeka di kantor camat Sembalun. Acara pembukaan kegiatan ini dihadiri oleh pemerintah desa, kecamatan, mahasiswa, dan tim dosen.

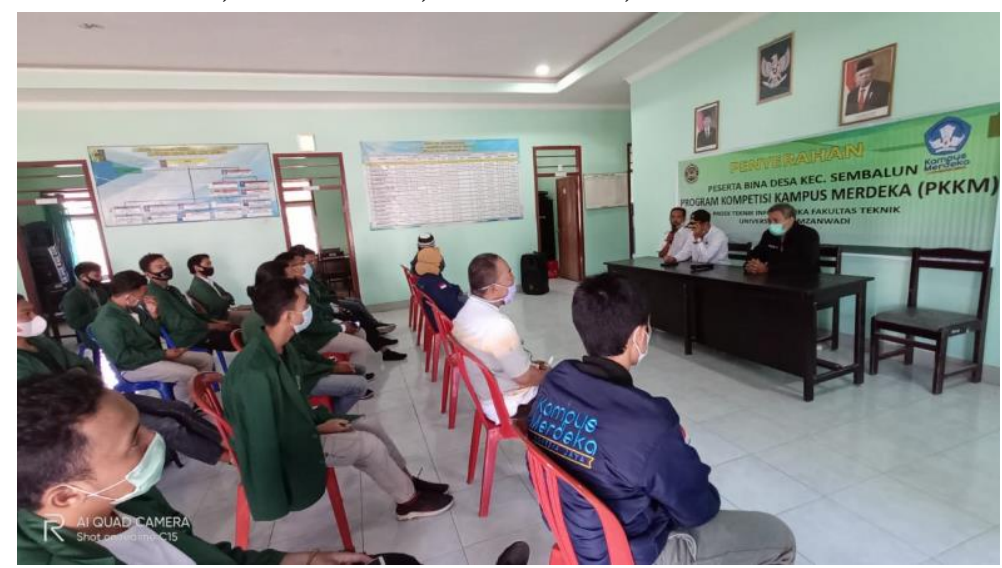

Gambar 1. Acara Pembukaan

Kemudian pada bulan Agustus tim dosen melakukan identifikasi permasalahan jaringan yang ada pada semua kantor desa di Kecamatan Sembalun. Tim dosen menemukan permasalahan yang hampir sama di semua kantor desa yang ada di Kecamatan Sembalun, yaitu tidak adanya koneksi internet. Berdasarkan hasil wawancara dengan beberapa kepala desa menyatakan bahwa sebelumnya pemerintah desa telah mendapatkan bantuan dari pemerintah daerah berupa infrastruktur jaringan, akan tetapi sering mengalami gangguan bahkan tidak bisa digunakan sampai saat ini.

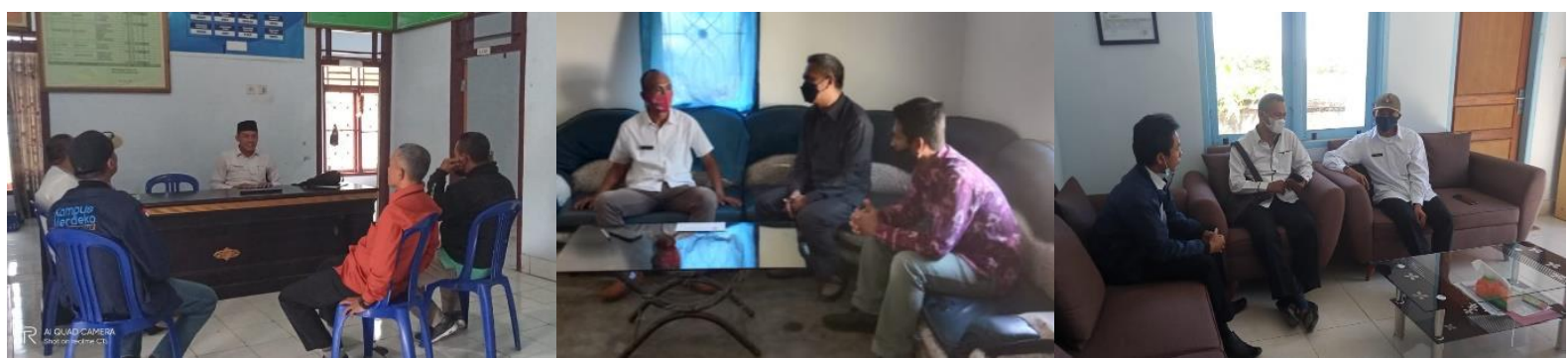

Gambar 2. Wawancara Dengan Kepala Desa Bilok Petung, Sajang, dan Sembalun

Selanjutnya tim dosen melakukan koordinasi untuk menentukan alternatif solusi yang tepat dan cepat berdasarkan hasil identifikasi permasalahan pada semua kantor desa di Kecamatan Sembalun. Setelah menentukan solusi yang terbaik tim dosen mempersiapkan alat dan bahan yang dibutuhkan dan sekaligus melakukan konfigurasi terhadap modem+router. 
Adapun langkah-langkah konfigurasi quick setup modem TP-Link 4G LTE Router sebagai berikut:

1. Terlebih dahulu masuk dengan menggunakan alamat http://tplinkmodem.net

2. Lalu pilih Quick Setup

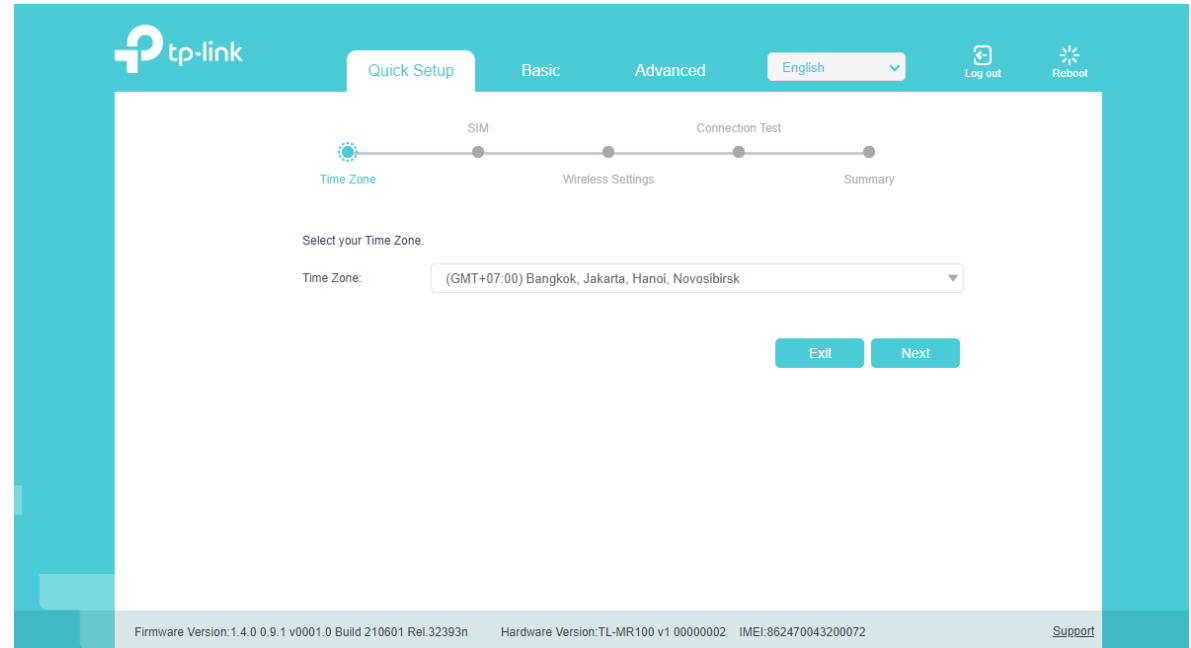

Gambar 3. Quick Setup Ganti atau ubah time zone menjadi Bangkok Jakarta lalu pilih next.

3. Setting SIM Card dengan mengecek kartu yang digunakan lalu pilih next.

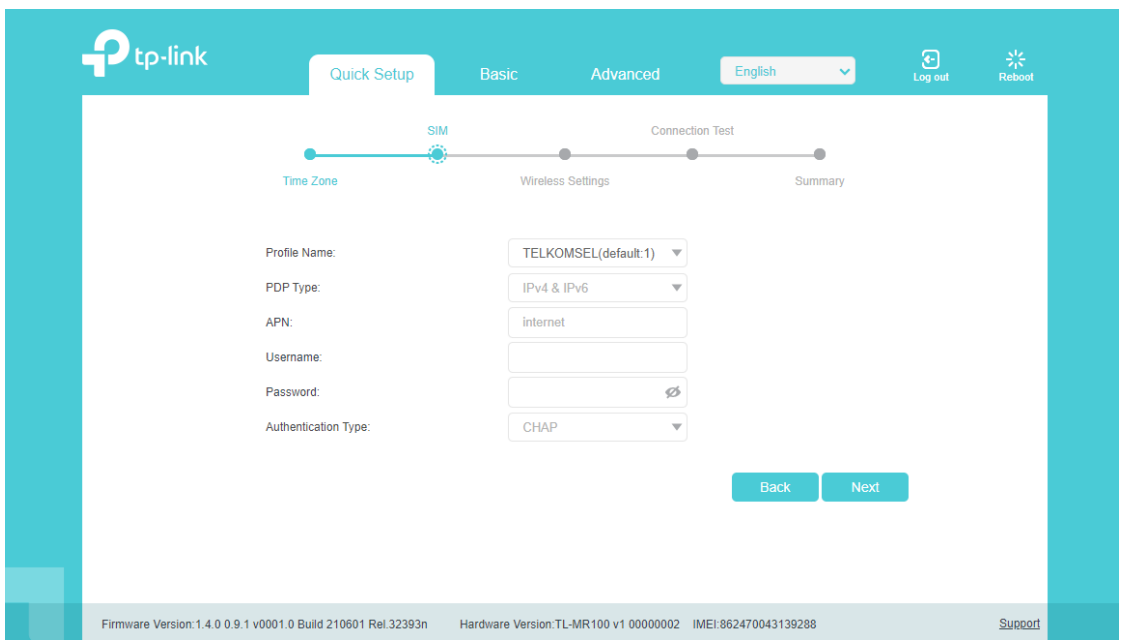

Gambar 4. Setting SIM Card

4. Konfigurasi wireless dengan mengganti nama jaringannya dengan nama yang diinginkan dan membuat password yang baru lalu pilih next. 


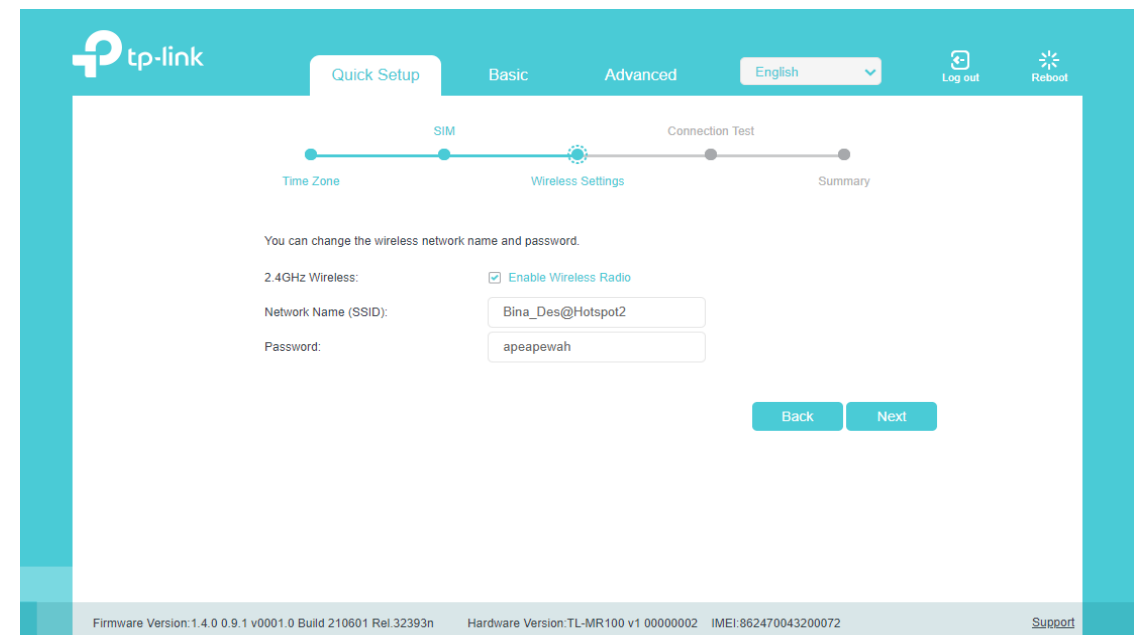

Gambar 5. Konfigurasi Wireless

5. Selanjutnya mengecek koneksi

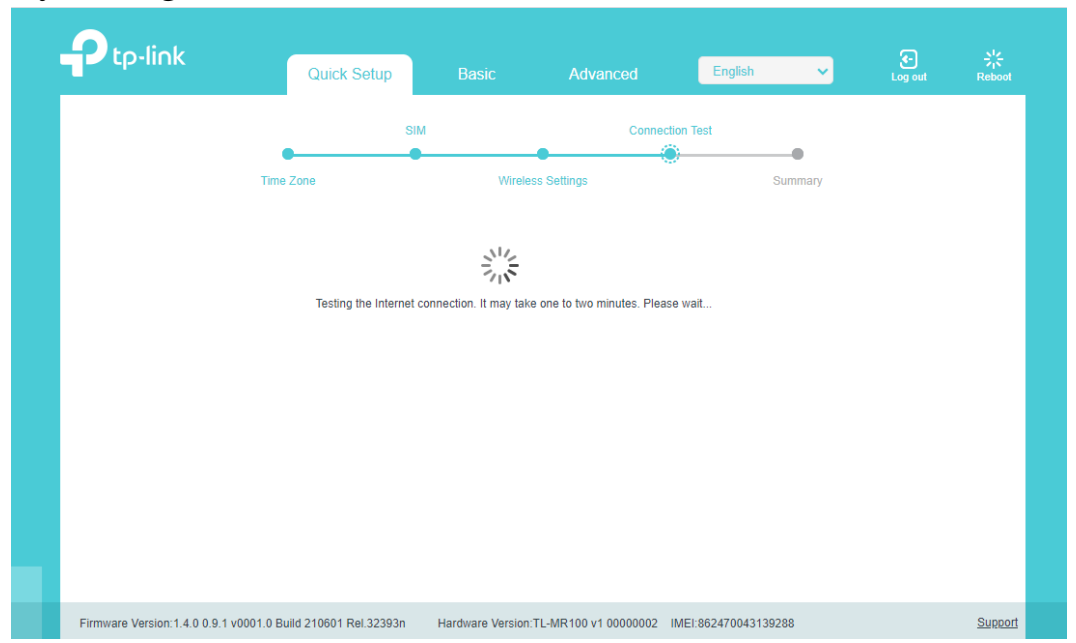

\section{Gambar 6. Tes Koneksi}

6. Hasil Koneksi ditandai dengan kata success

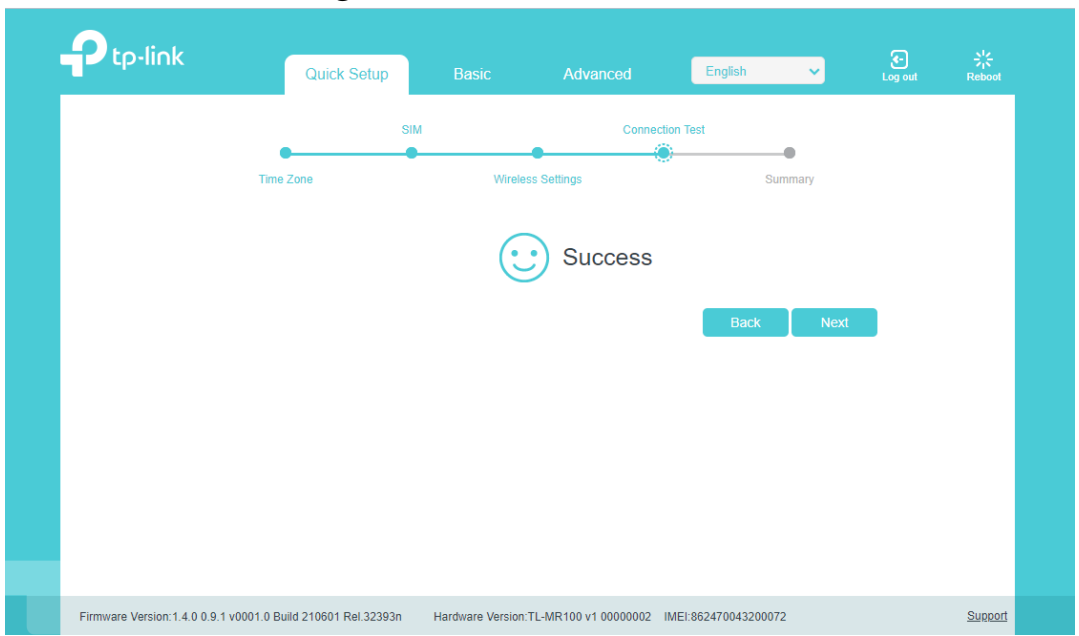

Gambar 7. Hasil Koneksi

Setelah melakukan konfigurasi modem TP-Link 4G LTE Router lalu dilanjutkan dengan pemasangan perangkat jaringan ke semua kantor desa yang ada di Kecamatan Sembalun. 


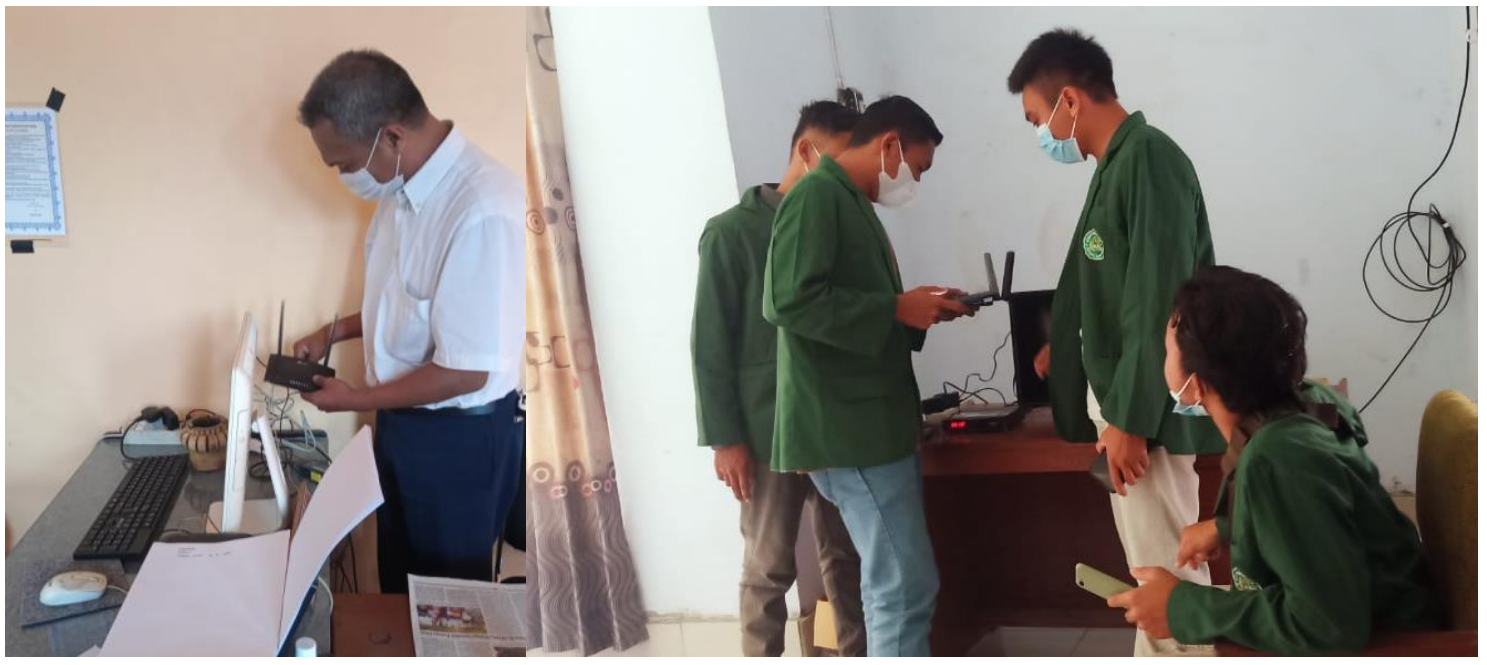

Gambar 8. Pemasangan Modem TP-Link 4G LTE Router

Pada tahap pemasangan ini, tim dosen dibantu oleh mahasiswa yang ada di setiap desa untuk melakukan pemasangan perangkat jaringan seperti pemasangan kabel pada konektor, menghubungkan setiap komputer ke router dan lain sebagainya. Selanjutnya melakukan pengujian koneksi internet terhadap semua perangkat jaringan yang telah dipasang. Setelah pengujian berhasil dan semua komputer dapat terhubung ke jaringan internet, lalu dilakukan sosialisasi kepada setiap pemerintah desa tentang bagaimana menggunakan dan pemanfaatan akses internet. Kegiatan sosialisasi ini sangat penting bagi masyarakat khususnya semua pemerintah desa yang ada di Kecamatan Sembalun sebagai wawasan dan pengetahuan dibidang teknologi informasi dan komunikasi. Ditegaskan pula dalam penelitian Sumbodo, dkk., (2017) menyatakan bahwa terdapat dampak positif dan negatif yang harus dikondisikan dengan kerja sama antar warga yang bersangkutan dan pro kontra yang terjadi di dalam masyarakat harus diselesaikan dengan penanaman wawasan dan pengetahuan.

Kemudian tim dosen melakukan evaluasi kembali untuk melihat sejauh mana pemanfaatan perangkat jaringan yang ada di semua kantor desa di Kecamatan Sembalun, serta perangkat jaringan tersebut berfungsi dengan baik atau tidak. Terakhir tahapan tindak lanjut atau pengembangan selanjutnya pada infrastruktur jaringan yang ada di semua kantor desa dengan menggunakan perangkat tambahan jaringan yaitu mikrotik dan sumber internetnya dari ISP seperti Telkom.

\section{PEMBAHASAN}

Pengabdian Bina Desa di Kecamatan Sembalun merupakan salah satu bagian dari Program Kompetisi Kampus Merdeka yang diselenggarakan oleh Program Studi Teknik Informatika Fakultas Teknik Universitas Hamzanwadi. Kegiatan Pengabdian Masyarakat ini melibatkan beberapa unsur diantaranya, 1) Program Studi Teknik Informatika Fakultas Teknik Universitas Hamzanwadi sebagai pelaksana Program Kompetisi Kampus Merdeka, terdiri dari dosen-dosen tetap Fakultas Teknik Universitas Hamzanwadi. 2) Kecamatan Sembalun yang terdiri dari enam desa yaitu Sembalun Bumbung, Sembalun Lawang, Sembalun Timba Gading, Sembalun, Sajang, dan Bilok Petung. Kegiatan pengabdian ini diawali dengan acara pembukaan yang dipimpin langsung oleh pak camat dan didampingi oleh sekretaris camat, serta dihadiri oleh mahasiswa, tim dosen, dan semua kepala desa atau staf yang mewakili se- 
kecamatan Sembalun. Selanjutnya tim dosen melakukan identifikasi terhadap permasalahan yang ada pada semua kantor desa di kecamatan Sembalun, salah satunya adalah jaringan internet.

Berdasarkan dari masalah di atas, tim dosen melakukan koordinasi dengan lembaga untuk mempersiapkan alat dan bahan yang dibutuhkan dalam membuat jaringan internet. Tim dosen melakukan pengecekan terhadap alat dan bahan yang disiapkan dari lembaga serta melakukan konfigurasi terhadap modem+router yang akan didistribusikan ke semua kantor desa di kecamatan Sembalun. Setelah melakukan konfigurasi, lalu tim dosen yang dibantu oleh mahasiswa untuk melakukan kegiatan pemasangan modem+router pada semua kantor desa di kecamatan Sembalun. Selama kegiatan pengabdian ini, berjalan dengan baik dan lancar. Sebagian besar pemerintah desa yang ada di Kecamatan Sembalun sangat antusias dengan kegiatan pengabdian ini, karena pemerintah desa dapat memanfaatkan teknologi dalam menyelesaikan pekerjaan yang berbasis online serta dapat meningkatkan pelayanan bagi masyarakat. Sejalan dengan pengabdian yang dilakukan oleh Mukhsin (2020) bahwa implementasi penerapan IT di pemerintahan desa adalah dengan mengupayakan tersedianya jaringan komputer, sumber daya manusia yang mumpuni dan tersedianya sarana serta prasarana yang memadai agar pelayanan kepada masyarakat dapat maksimal. Selain itu, dengan menggunakan sistem IT data-data masyarakat yang ada dapat tersimpan dengan aman dan rapi. Kemudahan yang didapat pun dapat mengefektifkan kinerja para aparat desa.

Dalam kegiatan pengabdian ini masih banyak terdapat kekurangan yang harus diperbaiki ataupun dilengkapi pada pengabdian berikutnya. Masih terbatasnya akses internet yang hanya dapat dilakukan pada kantor desa saja, akses internetnya menggunakan modem GSM, dan belum menerapkan perangkat mikrotik dalam infrastruktur jaringan, sehingga menyebabkan pengelolaan perangkat jaringan belum maksimal. Seperti dikemukakan pada penelitian Putra, dkk. (2020) penggunaan sistem keamanan jaringan dengan menggunakan mikrotik mampu meningkatkan sistem keamanan jaringan. Dengan adanya kegiatan ini, pihak desa merasa terbantu dalam mengawasi, dan mengatur bandwidth, sehingga layanan pada masyarakat dapat ditingkatkan. Hasil wawancara juga menunjukkan bahwa semua desa yang ada di Kecamatan Sembalun merasa terbantu dalam menyelesaikan pekerjaan dan dapat meningkatkan pelayanan bagi masyarakat. Sejalan dengan pengabdian yang dilakukan oleh Hariyanti, dkk. (2019) menyatakan setelah dilakukan instalasi dan perbaikan jaringan, akses Data Base dapat dilakukan dengan cepat sehingga mempermudah proses pembuatan surat dan mempercepat pelayanan yang dibutuhkan oleh masyarakat.

\section{SIMPULAN}

Setelah dilaksanakan, kegiatan ini dapat mencapai tujuan yang sebelumnya ditargetkan. Dengan adanya jaringan internet diharapkan dapat membantu semua pemerintah desa di Kecamatan Sembalun untuk melaksanakan tugas dengan maksimal khususnya pekerjaan yang berbasis online, serta dapat meningkatkan pelayanan bagi masyarakat. Kami menyadari pada kegiatan ini masih banyak kekurangan, diantaranya belum menerapkan mikrotik pada infrastruktur jaringan, sehingga pengelolaan perangkat jaringan belum maksimal dan diharapkan dapat dilakukan pada pengabdian selanjutnya. 
Sadali, M., Putra, Y. K., Yahya, Y., Dewi, I. K. (2021). Implementasi jaringan internet guna meningkatakan pelayanan pemerintah desa di Kecamatan Sembalun. ABSYARA: Jurnal Pengabdian Pada Masyarakat, 2(2), 264-273. doi:10.29408/ab.v2i2.4356

\section{PERNYATAAN PENULIS}

Artikel ini belum pernah dipublikasikan pada jurnal mana pun.

\section{DAFTAR PUSTAKA}

Hariyanti, N. K. D., Astawa, I. N. G. A., Suwintana, I. K., \& Sudiadnyani, I. G. A. O. (2019). Implementasi Jaringan Lan Dalam Upaya Peningkatan Pelayanan Di Kantor Desa Pikat Kecamatan Dawan Kabupaten Klungkung.

Kholisho, Y. N., Arianti, B. D. D., Jamaluddin, J., Wirasasmita, R. H., Ismatulloh, K., Uska, M. Z., \& Fathoni, A. (2021). Pelatihan pembuatan dan editing video bagi guru SD untuk menghadapi Era Industri 4.0. ABSYARA: Jurnal Pengabdian Pada Masyarakat, 2(1), 119-127.

Mukhsin, M. (2020). Peranan Teknologi Informasi dan Komunikasi Menerapkan Sistem Informasi Desa dalam Publikasi Informasi Desa di Era Globalisasi. Teknokom, 3(1), 715.

Narayanasamy, N. (2009). Participatory rural appraisal: Principles, methods and application. SAGE Publications India.

Pibriana, D., \& Ricoida, D. I. (2017). Analisis pengaruh penggunaan internet terhadap minat belajar mahasiswa (studi kasus: perguruan tinggi di Kota Palembang). JATISI (Jurnal Teknik Informatika dan Sistem Informasi), 3(2), 104-115.

Purbo, O.W. 2006. Buku Pegangan Internet Wireless dan Hotspot. Jakarta: PT. Elex Media Komputindo.

Purwanto, E. (2015). Implementasi Jaringan Hotspot Dengan Menggunakan Router Mikrotik Sebagai Penunjang Pembelajaran (Studi Kasus: Smk Sultan Agung Tirtomoyo Wonogiri). Jurnal Informa: Jurnal Penelitian dan Pengabdian Masyarakat, 1(2), 2027.

Putra, Y. K., Sadali, M., \& Mahpuz, M. (2020). Penerapan Mikrotik Dalam Mengembangkan Infrastruktur Jaringan Pada Kantor Desa Rumbuk Kecamatan Sakra. Infotek: Jurnal Informatika dan Teknologi, 3(2), 182-193.

Rasmila, R., Amalia, R., Jemakmun, J., \& Mukti, A. R. (2021). Pelatihan online internet sehat sebagai media pembelajaran bagi siswa-siswi SMK Nurul Huda Pemulutan Barat. ABSYARA: Jurnal Pengabdian Pada Masyarakat, 2(1), 26-31.

Riadi, I. (2011). Optimalisasi Keamanan Jaringan Menggunakan Pemfilteran Aplikasi Berbasis Mikrotik. Jurnal Sistem Informasi Indonesia, 1(1), 71-80.

Suhartini, S., Sudianto, A., Gunawan, I., Permana, B. A. C., Ahmadi, H., Fathurrahman, I., ... \& Nurhidayati, N. (2021). Pembinaan kewirausahaan berbasis teknologi untuk mengembangkan jiwa Technopreneurship. ABSYARA: Jurnal Pengabdian Pada Masyarakat, 2(1), 1-7.

Sumbodo, B. A. A., Dharmawan, A., \& Faizah, F. (2017). Implementasi Teknologi Internet Sebagai Solusi Pengentasan Masalah Komunikasi di Desa Nyamuk, Kecamatan Karimunjawa, Kabupaten Jepara. Jurnal Pengabdian Kepada Masyarakat (Indonesian Journal of Community Engagement), 2(2), 189-203. 
Sadali, M., Putra, Y. K., Yahya, Y., Dewi, I. K. (2021). Implementasi jaringan internet guna meningkatakan pelayanan pemerintah desa di Kecamatan Sembalun. ABSYARA: Jurnal Pengabdian Pada Masyarakat, 2(2), 264-273. doi:10.29408/ab.v2i2.4356

Towidjojo, R., \& Farhan, M. E. (2015). Router Mikrotik: Implementasi Wireless LAN Indoor. Jakarta: Jasakom, 2-26. 